\title{
Competency Analysis of Evaluation of Technology-Based Learning in Elementary Teachers in The City of Surakarta
}

\author{
Hasan Mahfud, Fadhil Purnama Adi, Idam Ragil Widianto Atmojo, Roy \\ Ardiansyah
}

Universitas Sebelas Maret

hasanmahfud449@gmail.com

Article History

accepted 24/09/2019 approved 01/10/2019 published 01/12/2019

\begin{abstract}
The purpose of the service is to train elementary school teachers to have the competence to make Technology-Based Learning Evaluation Instruments for Elementary Teachers in the City of Surakarta. In addition to training teachers, this service also aims to analyze teacher competencies in the Technology-Based Learning Evaluation Instrument for Elementary Teachers in Surakarta. The subject of this service is an elementary school teacher in the city of Surakarta. The method used in this service starts with Workshop, Practice, and Implementation. In conducting this training, the subjects were asked to take a test related to the preparation of Technology-Based Learning Evaluation Instruments for Elementary Teachers in the City of Surakarta. Analysis of the data used is pre-test and post-test. The result of this activity is that there is an increase in the knowledge and understanding of teachers regarding the preparation of Technology-Based Learning Evaluation Instruments for Elementary Teachers in the City of Surakarta.
\end{abstract}

Keywords: Subject spesific pedagogic, High order thinking skill, Learning

\begin{abstract}
Abstrak
Tujuan dari layanan ini adalah untuk melatih guru sekolah dasar agar memiliki kompetensi untuk membuat Instrumen Evaluasi Pembelajaran Berbasis Teknologi untuk Guru Sekolah Dasar di Kota Surakarta. Selain melatih guru, layanan ini juga bertujuan untuk menganalisis kompetensi guru dalam Instrumen Evaluasi Pembelajaran Berbasis Teknologi untuk Guru Sekolah Dasar di Surakarta. Subjek dari layanan ini adalah seorang guru sekolah dasar di kota Surakarta. Metode yang digunakan dalam layanan ini dimulai dengan Workshop, Praktek, dan Implementasi. Dalam melakukan pelatihan ini, para subjek diminta untuk mengikuti tes terkait dengan persiapan Instrumen Evaluasi Pembelajaran Berbasis Teknologi untuk Guru Sekolah Dasar di Kota Surakarta. Analisis data yang digunakan adalah pre-test dan post-test. Hasil dari kegiatan ini adalah bahwa ada peningkatan dalam pengetahuan dan pemahaman guru tentang persiapan Instrumen Evaluasi Pembelajaran Berbasis Teknologi untuk Guru Sekolah Dasar di Kota Surakarta.
\end{abstract}

Kata Kunci: Subject spesific pedagogic, High order thinking skill, Pembelajaran

Social, Humanities, and Education Studies (SHEs): Conference Series https://jurnal.uns.ac.id/shes

p-ISSN 2620-9284

e-ISSN 2620-9292 


\section{PENDAHULUAN}

Teknologi adalah bagian yang tidak bisa dipisahkan dari kegiatan manusia pada era ini. Era yang disebut sebagai era disrupsi yang bentuk implementasi nyatanya adalah Revolusi Industri 4.0 dan didalam pendidikan disebut sebagai Education 4.0. Oleh karena semua aspek kehidupan harus bisa beradaptasi atau bahkan mengakselerasi Era ini, sehingga tidak menjadi terisolasi karena tidak bisa mengikuti. Dalam dunia pendidikan hal ini berdampak pada fungsi guru baik dalam perencaan, pelaksanaan, dan penilaian hasil belajar. Hal ini tentunya harus berkorelasi dengan kebijakan pemerintah yakni pelaksanaan Kurikulum Tematik. Disinilah fungsi guru, yakni menjadi "jembatan" dalam pengembangan perencanaan, pelaksanaan, dan penilaian hasil belajar kurikulum Tematik dengan pengembangan teknologi. Namun, berdasarkan fakta yang ditemukan, guru masih mengalami kesulitan dalam membuat perencanaan, pelaksanaan, dan penilaian kurikulum Tematik yang terintegrasi dengan perkembangan teknologi. Kesulitan yang dihadapi guru adalah kurangnya pemahaman guru tentang perkembangan teknologi yang dapat digunakan oleh guru dalam pelaksanaan pembelajaran. Argumentasi ini berdasarakang angket yang telah berikan secara random kepada guru di wilayah kota surakarta, data yang ditemukan dari 100 guru yang diberi angket hampir 92\% mengatakan tidak mengetahui aplikasi atau teknologi apa saja yang dapat diintegrasikan di dalam pembelajaran khususnya dalam hal penilaian. Tentunnya hal ini menjadi ironi yang nyata karena perkembangan education 4.0 menuntut guru untuk menggunakan teknologi yang terbaru. Sebagaimana secara detail terdapa pada gambar dibawah ini.

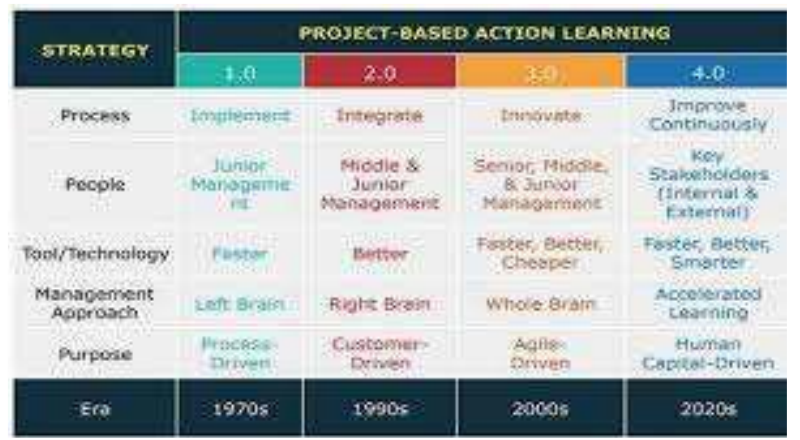

Gambar 1 Display kualifikasi pendidikan sesuai dengan perkembangan zamannya

Berdasarkan display pada gambar 1 nampak bahwa Education 4.0 menuntut adanya Teknologi yang digunakan Faster, Smarter, dan Better. Maknanya adalah keterbaruan atau perkembangan teknologi harus dimanfaatkan di dalam pelaksanaan pendidikan. Guru harus mampu memberikan fasilitas yang sesuai dengan tuntutan zaman. Faktanya guru masih melakukan evaluasi secara konvensional yakni dengan memberikan hardfile atau berkas soal atau dapat dikatakan masih konvensional. Hal ini juga dipengaruhi dari cara mengajar guru yang juga masih konvensional sebagai penggamabaran ilustrasi dibawah ini: 


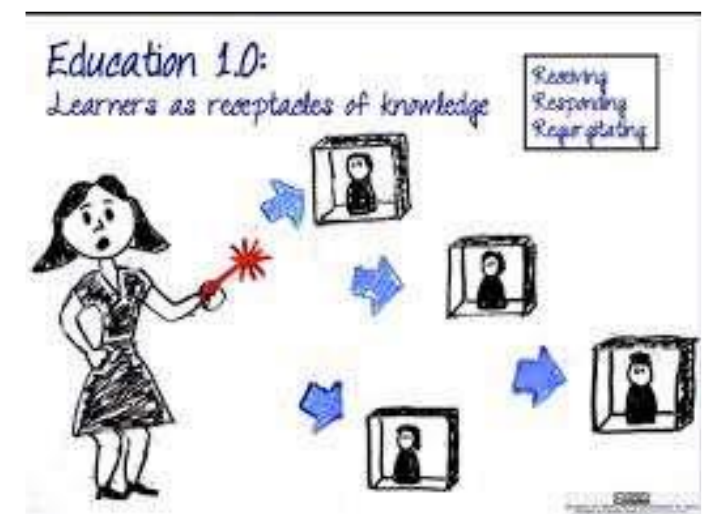

Gambar 2 Education 1.0 guru sebagai pusat informasi

llustrasi yang digambarkan pada gambar 2 menunjukkan bahwa cara penyampaian yang dilakukan oleh guru saat ini masih dalam skala education 1.0, oleh karenanya evaluasi yang dilakukan masih education 1.0. Hal ini harus segera diatasi dengan pemberian solusi yang tepat yakni dengan adanya pelatihan sarana-sarana yang dapat menunjang pembelajaran yang berbasis teknologi salah satunya evaluasi. Hal ini harus dikembangkan didalam kualitas kompetensi guru itu sendiri.

Kompetensi Guru merupakan indikator seorang guru profesional, kompetensi yang dimaksudkan Menurut Syaiful Sagala (2009: 209) kompetensi merupakan kelayakan untuk menjalankan tugas, kemampuan sebagai faktor penting bagi guru, oleh karena itu kualitas dan produktivitas kerja guru harus mampu memperlihatkan perbuatan profesional yang bermutu.

Adapun kompetensi guru (teacher competency) is the ability of a teacher to responsibility perform his or her duties appropriately. Kompetensi guru merupakan kemampuan seseorang guru dalam melaksanakan kewajiban-kewajiban secara bertanggung jawab dan layak (Usman, 2002). Terdapat empat kompetensi guru yang harus diimiliki oleh guru yakni Kompetensi Pedagogik, Komptensi Profesional, Kompetensi Sosial, dan Kompetensi Personal.

Keempat kompetensi ini memiliki urgensi dalam pelaksaaan proses evaluasi pembelajaran. Salah satu implikasinya adalah kemampuan guru dalam melihat tantangan dan peluang era education 4.0 sehingga dapat mengakselerasinya dengan menyediakan evaluasi pembelajaran yang terstandar dan terintegrasi dengan teknologi.

Permasalahan yang timbul saat ini adalah tentang rendahnya kemampuan guru dalam membuat evaluasi pembelajaran yang terintegrasi dengan teknologi untuk mengakselerasi Education 4.0. Urgensi dari hal ini adalah ketika evaluasi pembelajaran yang dilaksanakan tidak bersinergi dengan perkembangan zaman maka akan berdampak sistemik dan masif terhadap perkembangan kualitas pendidikan. Evaluasi adalah alat ukur dari pelaksanaan pembelajaran sehingga sentuhan akhir untuk menentukan kualitas pembelajaran adalah evaluasi pembelajarannya. Pembelajaran Tematik adalah pembelajaran yang menggunakan evaluasi komprehensif sehingga akan mengukur secara tema, sehingga apabila dintegrasikan dengan menggunakan teknologi akan mempermudah guru dalam melaksanaan evaluasi.

Berdasarakan hasil observasi awal yang dilakukan evaluasi pembelajaran yang dilaksanakan di sekolah belum terintegrasi dengan teknlogi dikarena beberapa hal yakni 1) Guru belum mengetahui aplikasi yang dapat digunakan untuk melakukan evaluasi pembelajaran tematik, 2) Gagap Teknologi, dan 3) kurangnya inisiatif guru untuk mempelajari lebih lanjut atau dapat dikatakn guru nyaman dengan zonanya. Apabila kondisi seperti ini terus menerus dibiarkan maka secara moril para akademisi 
dan praktis pendidikan telah tidak melaksanakan amanah dang tanggung jawabnya dalam menyelenggarakan pendidikan sesuai dengan amanah Undang-Undang dan Undang-Undang Dasar 1945. Solusi yang dapat diberikan adalah dengan mengadakan Pelatihan Permodelan Authentic Asssesment Berbantuan Google Form. Solusi ini diberikan mengingat permasalahan ini harus segera diselesaikan dengan peningkatan kualitas guru dalam membuat evaluasi pembelajaran berbantuan google form. Hal ini dikarenakan Evaluasi Pembelajaran yang berbatuan Google Form memiliki manfaat antara lain untuk mengakselarasi education 4.0 dengan mengoptimalkan cara atau teknik evaluasi yang berbantuan teknologi.

Evaluasi Pembelajaran adalah hal yang penting. Norman E. Gronlund (1976) berpendapat bahwa evaluasi merupakan proses yang dilakukan secara sistematis untuk membuat atau menentukan keputusan terkait dengan sejauh mana para siswa berhasil mencapai tujuan-tujuan pengajaran.. Purwanto (2002) juga mengemukakan pendapatnya tentang evaluasi dalam pendidikan. la menyatakan bahwa pengertian evaluasi adalah penilaian yang dilakukan terhadap kualitas tertentu dalam dunia pendidikan. Evaluasi sangat berkaitan erat dengan keputusan dan kebijakan yang diberikan pemerintah untuk meningkatkan kualitas pendidikan di Indonesia.

Google Form atau yang disebut google formulir adalah alat yang berguna untuk membantu anda merencanakan acara, mengirim survei, memberikan siswa atau orang lain kuis, atau mengumpulkan informasi yang mudah dengan cara yang efisin. Form juga dapat dihubungkan ke spreadsheet.

Berdasarkan hasil observasi yang dilakukan pada tanggal 21 Januari s.d. 25 Januari 2019 pada 2 orang kepala sekolah (SD Negeri Mangkubumen Kulon 83 dan SD N Dukuhan Kerten) diperoleh hasil bahwa pengetahuan dan kemampuan guru untuk membuat evaluasi yang berbantuan google form masih rendah. Dari total guru yang ada di kedua SD mitra sebanyak 35 orang, hanya 3 orang guru atau sekitar $(8,57 \%)$ yang sudah mengetahui dan menggunakan teknologi dalam pembelajaran tetapi untuk evaluasi masih semuanya belum. Berdasarkan hasil wawancara dengan kepala sekolah, diperoleh hasil bahwa guru guru mengalami kesulitan untuk membuat sebuah Evaluasi Pembelajaran yang berbatuanteknologi ini dikarenakan guru belum mengetahui dan memahami teknologi apa yang bisa diintegrasikan di dalam evaluasi pembelajaran.

Keberadaan Evaluasi Pembelajaran berbantuan Google Form di lingkungan sekolah khususnya sekolah dasar dalam upaya mengoptimalkan hasil dari setiap pelaksanaan proses pembelajaran sangatlah penting, oleh karenanya dibutuhkan pelatihan dan pendampingan yang dapat membantu guru untuk menguasai materi tentang Pelatihan Permodelan Authentic Asssesment Berbantuan Google Form baik dari sisi pembuatan dan penggunaan. Berdasarkan hasil studi pendahuluan yang dilakukan pada beberapa SD mitra tersebut diperoleh hasil bahwa kemampuan guru untuk memahami dan mengimplementasikan Authentic Asssesment Berbantuan Google Form masih rendah sehingga sangat mendesak dilakukan pemberian informasi dan pelatihan serta pendampingan Authentic Asssesment Berbantuan Google Form pada guru-guru tersebut

\section{METODE}

Subjek dalam pengabdian ini terdiri guru-guru sekolah dasar yang ada di wilayah administrasi kota Surakarta. Metode yang digunakan dalam pelatihan ini Workshop, Praktik, dan Implementasi. Teknik pengumpulan data menggunakan teknik tes. Teknik analisis yang digunakan menggunakan pre test dan post test.

\section{HASIL DAN PEMBAHASAN}

Berdasarkan hasil pre test yang dilakukan sebelum pelaksanaan kegiatan pengabdian menunjukkan bahwa guru-guru sekolah dasar di Surakarta yang terlibat 
sebagai peserta dalam kegiatan pengabdian dengan jumlah 50 guru yang terdiri dari lima sekolah dasar di kota Surakarta menunjukkan bahwa kemampuan guru dalam membuat evaluasi dan administrasi berbasis pada google forms. Hal ini ditunjukkan dari data yang menyatakan bahwa masih terdapat 32 guru atau sebesar $64 \%$ belum tuntas dalam mengerjakan soal pre test terkait dengan membuat evaluasi dan administrasi berbasis pada google forms di dalam pelaksanaan pembelajaran, atau hanya sekitar 18 guru (36\%) yang berhasil lulus. Guru yang berhasil lulus dalam pre test di dominasi oleh guru-guru muda yang masih hangat dengan ilmu-ilmu pendidikan terbaru, sedangkan guru-guru senior sedikit kesulitan dalam mengikuti kegiatan yang terkait dengan ilmu-ilmu pendidikan terbaru. Setelah dilaksanakan workshop tentang membuat evaluasi dan administrasi berbasis pada google forms kemampuan guru dalam membuat evaluasi dan administrasi berbasis pada google forms meningkat dengan tingkat ketercapaian ketuntasan mencapai 86\% atau sekitar 43 guru berhasil lulus dan sekitar 7 guru yang belum berhasil lulus. Hal ini menunjukkan terjadinya peningkatan sekitar $50 \%$ dari pre test ke post test yakni dari 18 guru menjadi 43 guru atau sekitar 25 guru. Secara grafis dapat dilihat dalam grafik 1.1 berikut:

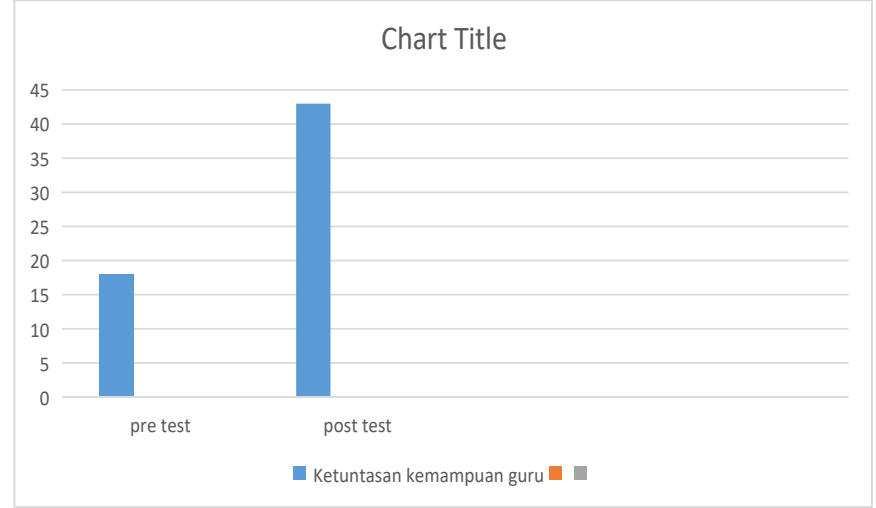

\section{Gambar 1.1 Grafik Hasil perbandingan pre test dan post test kemampuan guru SD}

Berdasarkan hasil pre test dan post test yang telah dilakukan ditemukan fakta bahwa pelatihan yang dilakukan memberikan dampak yang signifikan terhadap kompetensi guru. Pelatihan yang diberikan tentang membuat evaluasi dan administrasi berbasis pada google forms memberikan dampak yang signifikan terhadap kemampuan guru dalam hal membuat evaluasi dan administrasi berbasis pada google forms. Kegiatan workshop atau pelatihan dengan mendatangkan narasumber ahli yang merupakan pakar di bidang tersebut secara tidak langsung sudah memberikan dampak yang positif melalui proses komunikasi yang baik. Sebagaimana dijelaskan dalam Rosmawaty (2010) bahwa komunikasi kelompok adalah komunikasi dalam kelompok kecil orang, dengan tujuan antara lain untuk berbagi informasi, membantu mengembangkan gagasan bahkan membantu untuk memecahkan masalah, baik secara formal maupun tidak formal. Situasi formal yang dibangun ketika pelaksanaan Pelatihan atau Workshop akan membantu menyelesaikan permasalahan yang dihadapi oleh guru dalam hal membuat evaluasi dan administrasi berbasis pada google forms

\section{SIMPULAN}

Berdasarkan dari hasil kegiatan pelatihan atau workshop dapat disimpulkan bahwa dengan pelaksanaan workshop tentang membuat evaluasi dan administrasi berbasis pada google forms dapat meningkatkan kemampuan guru dalam menyusun Soal berbasis HOTs yang akan digunakan dalam pelaksanaan pembelajaran. Simpulan ini didapatkan dari hasil analisis pre test dan post test yang dilakukan ketika pelaksanaan kegiatan 


\section{DAFTAR PUSTAKA}

Arbain, N \& Shukor, N.A. (2015). The effect of Geogebra on Students Achievement. Johor Baru: Elsevier Itd

Lingguo, B. \& Robert, S.(2011). Model-Centered Learning: Pathways to Mathematical Understanding Using GeoGebra. Rotterdam: Sense Publishers.

Rostina Sundayana. (2013). Media Pembelajaran Matematika (untuk guru, calon guru, orang tua,

dan para pecinta matematika). Bandung: Alfabeta

Sagala,Syaiful . (2009). Konsep dan Makna Pembelajaran. Bandung : CV. ALFABETA

Usman, Moh. Uzer .(2002). Menjadi Guru Profesional, PT. Remaja Rosda Karya:

Bandung 